\section{TINJAUAN HUKUM TERHADAP CARA HAKIM MENYELESAIKAN SENGKETA WARIS ADAT ${ }^{1}$}

Oleh : Isabella Takapente ${ }^{2}$

\begin{abstract}
ABSTRAK
Tujuan dilakukannya penelitian ini yaitu untuk mengetahui bagaimanakah corak dan proses pewarisan hukum adat di Indonesia dan bagaimanakah cara hakim menyelesaikan sengketa hukum waris adat yang dengan metode penelitian hukum normatif disimpulkan bahwa: 1 . Hukum Adat Indonesia yang normatif pada umumnya menunjukkan corak Tradisional, keagamaan, kebersamaan, konkret dan Visual, terbuka dan sederhana, dapat berubah dan menyesuaikan, tidak dikodifikasi serta musyawarah dan mufakat dan mengenai proses pewarisannya sebelum pewaris meninggal dunia dilaksanakan dengan cara penerusan atau pengalihan, cara penunjukkan serta cara meninggalkan pesan atau wasiat dan sesudah pewaris meninggal dunia, dilaksanakan dengan penguasaan harta waris dan pembagian harta waris. 2. Cara hakim menyelesaikan sengketa hukum waris adat, yang pada dasarnya hukum adat itu tidak tertulis, hal ini terdapat dalam Pasal 10 ayat 1 dan Pasal 5 ayat 1 Undang-Undang Nomor 48 Tahun 2009 yang menentukan bahwa hakim dilarang menolak suatu perkara dan wajib menggali, mengikuti dan memahami nilai-nilai hukum dan rasa keadilan yang hidup dalam masyarakat. Ketentuan pasal ini akan menjadi salah satu dasar hukum bagi hakim untuk menemukan hukumnya berdasarkan hukum kebiasaan atau hukum adat serta berdasarkan Pasal 50 ayat 1 dan 2 yang mensyaratkan agar semua putusan pengadilan, selain memuat alasan dan dasar putusan, juga harus memuat pasal tertentu dari peraturan perundangundangan yang bersangkutan atau sumber hukum yang tidak tertulis yang dijabarkan untuk mengadili.
\end{abstract}

Kata kunci: waris adat; hakim;

\footnotetext{
${ }^{1}$ Artikel Skripsi. Dosen Pembimbing: Dr Cornelius Tangkere.SH.MH. Dr. Jemmy Sondakh.SH.MH

${ }^{2}$ Mahasiswa pada Fakultas Hukum Unsrat, NIM :16071101588
}

\section{PENDAHULUAN}

\section{A. Latar Belakang Penulisan}

Indonesia belum mempunyai UndangUndang Hukum Waris Nasional yang berlaku bagi seluruh rakyat Indonesia. Sehubungan dengan belum adanya undang-undang tersebut, di Indonesia masih diberlakukan 3 (tiga) sistem hukum kewarisan yakni hukum kewarisan Perdata Barat, Islam dan Adat. Hal ini disebabkan sifat pluralisme suku bangsa dan warga negara Indonesia.

\section{B. Perumusan Masalah}

1. Bagaimanakah corak dan proses pewarisan hukum adat di Indonesia?

2. Bagaimanakah cara hakim menyelesaikan sengketa hukum waris adat?

\section{Metode Penelitian}

Penelitian ini merupakan penelitian hukum normative.

\section{PEMBAHASAN}

\section{A. Corak Hukum Adat Dan Proses Pewarisan Hukum Adat Di Indonesia}

\section{Corak Hukum Adat}

Hukum Adat Indonesia yang normatif pada umumnya menunjukkan corak yang dapat diuraikan sebagai berikut :

1. Tradisional.

Hukum adat itu pada umumnya bercorak tradisional, artinya bersifat turun temurun, dari zaman nenek moyang sampai ke anak cucu sekarang keadaannya masih tetap berlaku dan dipertahankan oleh masyarakat bersangkutan. Misalnya dalam hukum kekerabatan adat orang Batak yang menarik garis keturunan lelaki, sejak dulu sampai sekarang tetap saja mempertahankan hubungan kekerabatan yang disebut "Dalihan Na Tolu".

2. Keagamaan.

Hukum Adat itu pada umumnya bersifat keagamaan (magis religius), artinya perilaku hukum atau kaidah-kaidah hukumnya berkaitan dengan kepercayaan terhadap yang gaib dan atau berdasarkan pada ajaran Ke Tuhanan Yang Maha Esa. Menurut kepercayaan bangsa Indonesia bahwa di alam semesta ini benda-benda itu serba berjiwa (animisme), benda-benda itu 
bergerak disekitar kehidupan manusia itu ada roh-roh halus yang mengawasi kehidupan manusia dan alam sejagad karena ada yang mengadakan, yaitu Yang Maha Pencipta.

3. Kebersamaan

Hukum Adat mempunyai corak yang bersifat kebersamaan (komunal), artinya ia lebih mengutamakan kepentingan bersama, dimana kepentingan pribadi itu diliputi oleh kepentingan bersama. Hubungan hukum antara anggota masyarakat yang satu dan yang lain didasarkan oleh rasa kebersamaan, kekeluargaan, tolong-menolong dan gotong-royong. Misalnya, rumah gadang di tanah Minangkabau dan tanah pusaka yang tidak terbagi-bagi secara individual melainkan menjadi milik kepentingan bersama.

4. Konkret dan Visual.

Corak hukum adat adalah " konkret" artinya jelas, nyata, berwujud dan visual artinya dapat terlihat, tampak, terbuka, tidak tersembunyi. Jadi sifat hubungan hukum yang berlaku dalam hukum adat itu "terang dan tunai", tidak samar-samar, terang disaksikan, diketahui, dilihat dan didengar orang lain. Misalnya dalam perjanjian jual beli tanah, dimana pihak pembeli dan penjual telah sepakat tetapi harga tanah belum dibayar dan tanah belum diserahkan penjualnya, biasanya pembeli memberi "panjer sebagai tanda jadi. Artinya si penjual tanah tidak boleh lagi menjual kepada orang lain.

5. Terbuka dan sederhana.

Corak hukum adat itu "terbuka" artinya dapat menerima masuknya unsur-unsur yang datang dari luar asal tidak bertentangan dengan jiwa hukum adat itu sendiri. Corak dan sifatnya yang sederhana, artinya bersahaja, tidak rumit, tidak banyak administrasinya, bahkan kebanyakan tidak tertulis, mudah dimengerti dan dilaksanakan berdasar saling percaya mempercayai.

6. Dapat berubah dan menyesuaikan.

Hukum adat itu dapat berubah menurut keadaan, waktu dan tempat. Adat yang nampak pada kita sekarang sudah jauh berbeda dari adat di masa Hindia Belanda.
7. Tidak dikodifikasi.

Hukum adat kebanyakan tidak ditulis, walaupun ada juga yang dicatat dalam aksara daerah, bahkan ada yang dibukukan dengan cara yang tidak sistematis, namun hanya sekadar sebagai pedoman bukan mutlak harus dilaksanakan, kecuali yang bersifat perintah Tuhan. Jadi hukum adat pada umumnya tidak dikodifikasi seperti hukum barat, yang disusun secara teratur dalam kitab yang disebut kitab perundangan. Oleh karenanya maka hukum adat itu mudah berubah, dan dapat disesuaikan dengan perkembangan masyarakat.

8. Musyawarah dan mufakat.

Hukum Adat mengutamakan adanya musyawarah dan mufakat, di dalam keluarga, di dalam hubungan kekerabatan dan ketetanggaan, baik untuk memulai suatu pekerjaan maupun dalam mengakhiri pekerjaan, apalagi yang bersifat "peradilan" dalam menyelesaikan perselisihan antara yang satu dan yang lain. Di dalam penyelesaian perselisihan selalu diutamakan jalan penyelesaian secara rukun dan damai dengan musyawarah dan mufakat, dengan saling memaafkan, tidaklah tergopoh-gopoh begitu saja langsung menyampaikan ke pengadilan negara.

\section{Proses Pewarisan dalam hukum waris adat}

a. Sebelum pewaris meninggal dunia.

Di dalam hukum waris adat proses pewarisan dapat dilaksanakan dengan cara $:^{3}$

1) Cara penerusan atau pengalihan

Pada saat pewaris masih hidup, sering kali pewaris melakukan penerusan atau pengalihan kedudukan atau jabatan adat, hak dan kewajiban harta kekayaan kepada ahli warisnya. Cara ini biasanya berlangsung menurut hukum adat setempat, misalnya terhadap kedudukan, hak dan kewajiban dan harta kekayaan yang tidak terbagi-bagi kepada anak laki-laki sulung atau bungsu di Tanah Batak atau kepada anak perempuan sulung di Minangkabau atau kepada tunggu-tubang di Semendo. Ada pula pemberian harta kekayaan tertentu sebagai

\footnotetext{
${ }^{3}$ Ibid, hal.45
} 
bekal kekayaan untuk kelanjutan yang diberikan oleh pewaris kepada anakanaknya pada saat anaknya akan kawin dan mendirikan rumah baru, di Batak tersebut Manjae. Pemberian itu dapat berupa rumah, tanah, sawah,perhiasan. Di Batak biasanya untuk anak laki-laki diberi bekal rumah atau tanah dan untuk anak perempuannya bekal perhiasan.

2) Cara penunjukan

Pada saat pewaris masih hidup, ia menunjuk kepada ahli waris atas hak dan kewajiban atas harta tertentu, dimana perpindahan penguasaan dan pemilikan baru berlaku dengan sepenuhnya kepada ahli warisnya pada saat si pewaris sudah meninggal dunia.

3) Cara meninggalkan pesan atau wasiat Biasanya pesan atau wasiat ini diucapkan atau dituliskan pada saat pewaris masih hidup, akan tetapi dalam keadaan sakit parah atau mau pergi jauh dan ada kemungkinan tidak kembali lagi ke kampong halamannya. Hal ini biasanya harus diucapkan atau ditulis dengan terang dan disaksikan oleh para ahli waris, anggota keluarga, tetangga, dan tua-tua desa.

\section{b. Sesudah Pewaris meninggal dunia.}

Sesudah si pewaris meninggal dunia, terkadang timbul permasalahan apakah harta warisan diteruskan kepada ahli warisnya dalam keadaan terbagi-bagi atau tidak terbagi-bagi. Apabila harta waris diteruskan dalam keadaan tidak terbagi-bagi maka perlu ditentukan harta waris tersebut berada dalam penguasaan.

1. Penguasaan Harta Waris

a) Penguasaan janda

Pada umumnya di Indonesia apabila ahli waris meninggal dunia meninggalkan istri dan anak-anak, maka harta warisan terutama harta bersama suami dan istri yang didapat sebagai hasil pencarian bersama selama perkawinan mereka dapat dikuasai oleh janda almarhum untuk kepentingan kelanjutan hidup dan anak-anak ditinggalkan.

b) Penguasaan Anak

Apabila janda dari almarhum pewaris sudah tua dan anak-anak sudah dewasa dan berumah tangga, maka harta warisan yang diteruskan dalam keadaan tidak terbagi-bagi tersebut dikuasai dan diatur oleh salah satu anak-anaknya yang dianggap cukup cakap dalam mengurus dan mengatur harta warisan tersebut.

c) Penguasaan Anggota Keluarga

Apabila pewaris meninggalkan anakanak yang masih kecil dan belum dewasa, serta tidak ada jandanya yang dapat bertanggung jawab mengurus harta warisannya, maka penguasaan atas harta warisan yang diteruskan dalam keadaan tidak terbagi-bagi tersebut diberikan kepada orangtua pewaris, bila sudah tidak ada lagi, maka akan dikuasai oleh saudara-saudara pewaris yang seketurunan atau dari kerabat yang paling dekat.

d) Penguasaan Tua-tua Adat

Apabila harta warisan tersebut merupakan harta pusaka tinggi, misalnya keris, tombak,rencong, pedang, dan jimat. Dalam hal ini penguasaannya ada pada tetua adat (kepala adat).

\section{Pembagian Harta Waris}

Apabila harta warisan diteruskan dalam keadaan tidak terbagi-bagi, maka perlu ditentukan kapan waktu pembagiannya dan bagaimana cara pembagian itu akan dilaksanakan sebagai berikut :

a) Waktu pembagian.

Pada umumnya hukum adat tidak menentukan kapan waktunya harta warisan tersebut akan dibagi,namun menurut hukum adat waktu pembagian warisan biasanya dilakukan setelah upacara selamatan terhadap pewaris yang meninggal dunia.

b) Juru bagi.

Biasanya anggota keluarga/kerabat, yaitu :

- Orangtua yang masih hidup;

- Janda atau duda pewaris;

- Anak laki-laki atau anak perempuan tertua;

- Anak keluarga tertua yang dipandang jujur, adil dan bijaksana;dan

- Anggota kerabat tetangga, pemuka masyarakat atau pemuka agama 
diminta, ditunjuk atau dipilih oleh para ahli waris.

c) cara pembagian harta waris.

Dalam hukum adat biasanya di dasarkan atas pertimbangan tertentu mengingat wujud benda dan kebutuhan dari para ahli waris yang bersangkutan. Jadi walaupun hukum waris adat mengenal asas kebersamaan hak tidak berarti, bahwa setiap ahli waris akan mendapat bagian harta warisan dalam jumlah yang sama, dengan nilai harga yang sama atau menurut banyaknya bagian yang sudah ditentukan.

\section{B. Cara Hakim Menyelesaikan Sengketa Hukum Waris Adat}

Di Indonesia, dasar hakim dalam memutus dalam suatu perkara adalah undang-undang, jika dalam suatu undang-undang tidak lengkap, tidak jelas, maka hakim harus mencari dan menemukannya sendiri. Hakim harus menemukan hukum (rechtsvinding). Penemuan hukum adalah suatu proses penemuan hukum oleh hakim atau aparat hukum lainnya yang ditugaskan untuk menerapkan peraturan hukum umum pada peristiwa hukum konkret.

Adanya penemuan hukum, dilatarbelakangi dari kesulitan hakim pada waktu berusaha memahami maksud pembuat undang-undang sebagai dasar mengadili, karena :

1. substansi undang-undang tidak pernah lengkap di tengah-tengah dinamika sosial;

2. hakim kesulitan memahami maksud dan tujuan pembuat undang-undang;

3. dalam hal bahasa, kalimat, terminology dalam undang-undang bersifat teknis umum, luas, abstrak, normatif dan ideal;

4. mengisi kekosongan hukum dan memberi makna dan jiwa dalam undangundang;

5. persoalan yang dihadapi bersifat riil, konkret, dan kontekstual. ${ }^{4}$

Hakim tidak boleh menolak untuk memeriksa suatu perkara yang ada yang diajukan ke pengadilan dengan dalih, bahwa dasar hukum tidak ada atau kurang jelas, tetapi hakim wajib memeriksa dan mengadilinya, karena hakim dianggap tahu tentang hukum (Ius Curia Novit). Hal ini sesuai dengan Pasal 10 ayat 1 Undang-Undang Nomor 48 Tahun 2009 tentang Kekuasaan Kehakiman yang menegaskan, bahwa "pengadilan dilarang menolak untuk memeriksa, mengadili, dan memutus suatu perkara yang diajukan dengan dalih bahwa dasar hukum tidak ada atau kurang jelas, melainkan wajib memeriksa dan mengadilinya".

Pasal 5 ayat 1 Undang-Undang Nomor 48 Tahun 2009 tentang Kekuasaan Kehakiman menyatakan, bahwa "hakim dan hakim konstitusi wajib menggali, mengikuti, dan memahami nilai-nilai hukum dan rasa keadilan yang hidup dalam masyarakat". Dalam rangka menggali rasa keadilan yang hidup dalam masyarakat, ada kalanya hakim dalam memutuskan suatu perkara menerapkan hukum adat. Oleh karena itu, hakim diharapkan mampu menggali hukum positif yang baru. Hakim harus memiliki ketajaman intektual yang tinggi mengenai hukum yang ada dalam masyarakat yang merupakan hukum yang tidak tertulis namun ditaati dan dihormati dalam masyarakat.

Dalam Pasal 50 ayat 1 Undang-Undang Nomor 48 Tahun 2009 tentang Kekuasaan Kehakiman menegaskan, bahwa " putusan pengadilan selain harus memuat alasan dan dasar putusan tersebut, juga memuat pasal tertentu dari peraturan perundang-undangan yang bersangkutan atau sumber hukum tak tertulis yang dijadikan dasar untuk mengadili".

Berdasarkan pasal diatas hakim atau pengadilan dalam membuat putusan haruslah disertai dengan adanya alasan-alasan yang ada, dalam hal ini hukum tidak tertulis yang merupakan sumber hukum alternatif di samping hukum tertulis. Pada dasarnya, kegiatan penemuan berkenaan dengan hal memperoleh pengetahuan tentang fakta dan hukum, dalam hal menelusuri dan menimbangnimbang kepentingan-kepentingan dan nilainilai dan berkenan dengan usaha untuk mencapai sebuah putusan hukum yang adil. Putusan hakim yang demikian itu disebut dengan "yurisprudensi". Tujuannya adalah untuk menghindari "disparitas" putusan hakim dalam perkara yang sama. ${ }^{5}$ Yurisprudensi 
berarti pada umumnya, yaitu pelaksanaan hukum dalam hal konkret terjadi tuntutan hak yang dijalankan oleh suatu badan yang berdiri sendiri dan diadakan oleh negara serta bebas dari pengaruh apa atau siapapun dengan memberikan putusan yang bersifat mengikat dan berwibawa.

Sudikno Mertokusumo berpendapat, bahwa yurisprudensi atau putusan pengadilan merupakan produk yudikatif yang berisi kaidah atau peraturan hukum yang mengikat pihakpihak yang bersangkutan atau terhukum. ${ }^{6}$ Dengan demikian, putusan pengadilan hanya mengikat orang-orang tertentu saja dan tidak mengikat setiap orang setiap orang secara umum seperti undang-undang. Putusan berisi kaidah-kaidah hukum sejak dijatuhkan sampai dilaksanakan. Sejak dijatuhkan putusan pengadilan mempunyai kekuatan mengikat bagi para pihak yang berperkara, mengikat para pihak untuk mengakui eksistensi putusan tersebut. Putusan pengadilan mempunyai kekuatan yang berlaku untuk dilaksanakan sejak putusan itu memperoleh kekuatan hukum yang tetap. Setelah dilaksanakan putusan pengadilan itu hanyalah merupakan sumber hukum.

Berdasarkan Pasal 1917 BW, suatu putusan hakim itu hanya mengikat pihak-pihak yang bersangkutan dan tidak mengikat hakim lain yang akan memutus perkara atau peristiwa yang serupa. Hakim tidak perlu mengikuti putusan-putusan terdahulu mengenai perkara sejenis, karena di Indonesia, pada dasarnya tidak terikat pada asas precedent atau putusan hakim yang terdahulu mengenai perkara atau persoalan hukum yang serupa dengan yang akan diputusnya. Dengan demikian, kalau ada seorang hakim hendak memutus perkara, ia tidak wajib untuk mengikuti atau terikat pada putusan pengadilan yang pernah dijatuhkan mengenai perkara yang sama atau serupa dengan yang akan diputusnya, inilah yang berlaku di Indonesia ${ }^{7}$

Dalam peradilan mengenal 2 (dua) jenis yurisprudensi, yaitu yurisprudensi biasa dan yurisprudensi tetap, yaitu :

1. yurisprudensi biasa adalah setiap putusan hakim yang disusun secara

\footnotetext{
${ }^{6}$ Ibid, hal. 45

${ }^{7}$ Ibid, hal.112
}

sistematis dari peradilan tingkat pertama sampai tingkat kasasi.

2. yurisprudensi tetap adalah suatu kaidah atau ketentuan dalam putusan pengadilan kemudian diikuti oleh para hakim dalam putusannya dan dianggap menjadi bagian dari keyakinan umum. ${ }^{8}$

Dalam praktik bahwa hakim itu, cendrung mengikuti putusan lain sejenis. Ada beberapa alasan yang dapat dikemukakan :

1. Alasan psikologis, yaitu putusan hakim punya kekuasaan karena hakim lebih tinggi sebagai pengawas dan lebih banyak pengalaman;

2. Alasan praktis, yaitu apabila perkara sejenis diputus akan menimbulkan potensi untuk diajukan banding;

3. Alasan persesuaian pendapat, yaitu karena hakim sependapat dengan isi putusan tersesut. $^{9}$

Yurisprudensi diartikan sebagai putusanputusan hakim atau pengadilan yang telah berkekuatan hukum tetap dan dibenarkan oleh Mahkamah Agung sebagai kasasi atau putusan Mahkamah Agung sendiri yang sudah berkekuatan hukum tetap. Dengan demikian, tidak semua putusan hakim pada tingkat satu atau pada tingkat banding dapat dikatakan sebagai yurisprudensi harus melalui proses "eksaminasi" dan "notasi" dari Mahkamah agung dengan rekomendasi sebagai putusan yang telah memenuhi standar hukum yurisprudensi. ${ }^{10}$

Hasil penelitian BPHN tahun 1995 menyatakan, bahwa suatu putusan hakim dapat disebut sebagai yurisprudensi apabila putusan hakim ini mempunyai unsur-unsur sebagai berikut :

1. Putusan atas suatu peristiwa hukum yang belum jelas pengaturan perundangundangannya.

2. Putusan tersebut harus merupakan putusan yang telah berkekuatan hukum yang tetap.

3. Telah berulang kali dijadikan dasar untuk memutus perkara yang sama.

\footnotetext{
${ }^{8}$ Sudikno Mertokusumo, Penemuan Hukum, Liberty, Yogyakarta,1999. hal.51.

${ }_{9}^{9}$ Ellyne D Poespasari, Op-cit, hal.140

${ }^{10}$ Nurul Elmiyah, Rosa Agustina dan Erman

Rajagukguk, Hukum Adat dalam Putusan Pengadilan, Lembaga Studi Hukum dan Ekonomi, Fakultas Hukum Universitas Indonesia, 2007, hal.9
} 
4. Putusan tersebut telah memenuhi rasa keadilan.

5. Putusan tersebut dibenarkan oleh Mahkamah Agung. ${ }^{11}$

Yahya Harahap dalam Varia Peradilan mengatakan, bahwa ada beberapa fungsi yurisprudensi, yaitu:

1. Menciptakan standar hukum atau to settle law standard yurisprudensi sebenarnya berpatokan pada parameter rasional, praktis dan aktual, sehingga putusan the maturity of law dalam kehidupan bangsa.

2. Membantu terwujudnya unified legal frame work (landasan hukum yang sama) serta unified legal opinion (keseragaman hukum yang sama).

3. Menegaskan kepastian hukum, untuk mencegah putusan yang bersifat disparitas antara putusan yang satu dan yang lainnya. ${ }^{12}$

Yahya Harahap dalam Varia Peradilan juga mengatakan, bahwa fungsi yurisprudensi sebagai judge made law, yaitu untuk mengatasi kevakuman hukum atau kekosongan hukum sampai adanya kodifikasi hukum yang lengkap dan baku, sehingga baik menurut UndangUndang Dasar Tahun 1945 ( Pasal 24 sebelum amandemen atau Pasal 24 A setelah amandemen) maupun Pasal 1 UU Nomor 48 Tahun 2009 tentang Kekuasaan Kehakiman, yaitu hakim dalam melaksanakan fungsi dan kewenangan kekuasaan kehakiman itu diberikan otonomi kebebasan secara luas yang meliputi : ${ }^{13}$

1. Menafsirkan peraturan perundangundangan.

2. Mencari dan menemukan asas-asas dan dasar-dasar hukum.

3. Mencipta hukum baru apabila menghadapi kekosongan peundang-undangan.

4. Memiliki otonomi yang bebas mengikuti yurisprudensi.

Berdasarkan pada beberapa pendapat tentang yurisprudensi sebagaimana dikemukakan diatas, maka dapat disimpulkan bahwa yurisprudensi bukan hanya sekadar

\footnotetext{
${ }^{11}$ Ellyne D Poespasari, Op-cit, hal.141.

${ }^{12}$ Yahya Harahap, Kedudukan Janda, Duda, Anak Angkat dalam Hukum Adat, 1993, Citra Aditya Bakti, Jakarta, 1993, hal.146-148.

${ }^{13}$ Ibid, hal.114.
}

pegangan hakim dalam melaksanakan tugas peradilan, namun juga dapat bermanfaat sebagai pembentukan hukum. Dengan demikian, bahwa hakim (Mahkamah Agung) melalui putusan yurisprudensinya dapat memegang peranan penting dalam mewujudkan perkembangan hukum adat.

Berdasarkan ketentuan Pasal 1 ayat 3 Perubahan Ketiga UUD 1945, negara Indonesia merupakan negara hukum. Namun sebelum dilakukan amandemen terhadap UUD 1945, konsep negara hukum dituangkan dalam Penjelasan Umum UUD 1945 dengan menyebutkan, bahwa negara Indonesia adalah negara yang berdasarkan atas hukum (rechtsstaat) tidak berdasarkan atas kekuasaan belaka (machsstaat). Dalam negara hukum, rakyat dan pemerintah harus menjunjung tinggi hukum dan berbuat sesuai dengan hukum. Terkait dengan itu, maka Sudikno Mertokusumo, ${ }^{14}$ menyatakan, bahwa hukum itu mengabdi pada tujuan hukum negara untuk menyelenggarakan keadilan dan ketertiban demi mewujudkan masyarakat adil dan makmur sebagaimana tercantum dalam pembukaan UUD 1945.

Terkait dengan negara hukum, bahwa UUD 1945 menentukan bahwa salah satu prinsip dari negara hukum adalah adanya penyelenggaraan kekuasaan kehakiman yang merdeka guna menegakkan hukum dan keadilan. Dalam hal ini diwujudkan dalam Pasal 24 ayat 1 Perubahan Ketiga UUD 1945 yang menyatakan, bahwa kekuasaan kehakiman merupakan kekuasaan yang merdeka untuk menyelenggarakan peradilan guna menegakkan hukum dan keadilan. Berdasarkan ketentuan Pasal 24 ayat 1 Perubahan Ketiga UUD 1945 tersebut kemudian dijabarkan dalam Pasal 1 angka 1 Undang-Undang Nomor 48 Tahun 2009 tentang Kekuasaan Kehakiman.

Pasal 1 angka 1 UU Nomor 48 Tahun 2009 tentang Kekuasaan Kehakiman tersebut menentukan bahwa kekuasaan kehakiman adalah kekuasaan negara yang merdeka untuk menyelenggarakan peradilan guna menegakkan hukum dan keadilan berdasarkan Pancasila, demi terselenggaranya Negara Hukum Republik Indonesia. Oleh karena itu, kekuasaan

\footnotetext{
${ }^{14}$ Sudikno Mertokusumo, Bab-bab tentang Penemuan Hukum, PT Citra Aditya Bakti, Bandung, 1993, hal.71.
} 
kehakiman sebagai penyelenggara peradilan merupakan unsur yang sangat penting dalam menegakkan hukum dan keadilan demi terselenggaranya Negara Hukum Republik Indonesia. Sudikno Mertokusumo, 15 menyatakan, bahwa penemuan merupakan suatu proses pembentukan hukum oleh hakim atau petugas hukum lainnya dengan cara mengkonkretisasi undang-undang yang bersifat umum untuk diterapkan pada peristiwa konkret yang bersifat khusus. Hal ini tidak berbeda dengan pendapat Arif B. Sidharta, ${ }^{16}$ yang mengemukakan bahwa penemuan hukum merupakan tindakan yang menghubungkan fakta-fakta yang telah diidentifikasi dengan sumber-sumber hukum tertentu.

Sebagaimana diketahui bahwa kegiatan hakim ketika dihadapkan pada suatu perkara, maka hakim mengualifikasi peristiwa konkret menjadi peristiwa hukum kemudian menerapkan peraturan hukum terhadap peristiwa hukum dan kemudian mengontitusikan, yaitu memberi hukumnya. Dari kegiatan hakim tersebut, penemuan hukum dapat dilakukan ketika menghubungkan peristiwa konkret yang sudah dikonstatasi tersebut dengan sumber-sumber hukum. Oleh sebab itu, ada suatu problematic dari hakim berkaitan dengan penemuan hukum yang dilakukan. Bagaiman hakim menghubungkan peristiwa konkret tersebut dengan sumbersumber hukum, dan dari mana hukum tersebut ditemukan. ${ }^{17}$

Berkaitan dengan penemuan hukum oleh hakim, Undang-Undang Nomor 48 Tahun 2009 tentang Kekuasaan Kehakiman menentukan beberapa ketentuan yang harus diperhatikan oleh hakim, yaitu diantaranya berdasarkan ketentuan pada Pasal 4 ayat 1 Undang-Undang Nomor 48 Tahun 2009, bahwa pengadilan mengadili menurut hukum. Oleh sebab itu, hakim dalam melaksanakan tugasnya di pengadilan harus sesuai dengan hukum. Dalam sistem hukum positif yang dianut di Indonesia, sumber hukum utama bagi hakim dalam

\footnotetext{
${ }^{15}$ Sudikno Mertokusumo, Penemuan Hukum Sebuah Pengantar, Liberty, Yogyakarta, 2007, hal.37..

${ }^{16}$ Arif B. Sidharta, Penalaran Hukum, Loka Latih Studi Hukum Kritis dan Pluralisme Hukum, Fakultas Hukum Universitas Tanjungpura Pontianak, 2005, hal.44.

${ }^{17}$ Ellyne D Poespasari, Op-cit, hal.143.
}

mengadili dan memutus suatu perkara adalah undang-undang.

Tugas hakim adalah menetapkan peristiwa konkret dan menetapkan undang-undang dalam peristiwa konkretnya dan kemudian menemukan hukumnya untuk menerapkan peristiwa konkret. Dalam melakukan tugasnya, hakim tidak selalu dapat menemukan hukumnya dalam undang-undang, karena undang-undang tidak selamanya jelas dan lengkap mengatur peristiwa konkret yang dihadapkan kepada hakim. Oleh karena itu, agar hakim dapat menemukan hukumnya terlebih dahulu harus menjelaskan, menafsirkan, atau melengkapi peraturan perundang-undangan dengan menggunakan metode penemuan hukum.

Metode penemuan hukum digunakan sebagai upaya bagaimana cara menjelaskan atau menafsirkan dan melengkapi peraturan perundang-undangannya dalam pemeriksaan perkara, apabila tidak jelas dan/atau tidak lengkap peraturan perundang-undangannya sehingga dapat ditetapkan hukumnya terhadap peristiwa yang konkret. Dalam situasi di mana undang-undang tidak jelas dan/atau tidak lengkap mengatur tentang suatu peristiwa konkret, maka hakim dituntut untuk tetap menemukan hukumnya, yaitu dengan cara kebebasan hakim atau kekuasaan kehakiman yang merdeka, dimana hakim diberi kewenangan untuk melakukan penafsiran (interpretasi) dan/atau penalaran hukum.

Gregory Leyn, ${ }^{18}$ menyatakan dalam metode interpretasi merupakan metode yang digunakan dalam upaya menemukan dan menyajikan makna yang sebenarnya dari undang-undang. Adapun menurut Sudikno Mertokusumo, ${ }^{19}$ penafsiran oleh hakim merupakan penafsiran atau penjelasan yang harus menuju kepada penerapan atau tidak menerapkan suatu peraturan hukum umum terhadap peristiwa konkret yang dapat diterima oleh masyarakat.

Beberapa metode interpretasi yang lazim digunakan, yaitu :

1. Interpretasi gramatikal/bahasa, yaitu merupakan metode yang digunakan

\footnotetext{
${ }^{18}$ Gregory Leyn, Hermeneutika Hukum, Sejarah, Teori Politik (terjemahan M. Khozim), Nusa Media, Bandung, 2008, hal.141.

${ }^{19}$ Sudikno Mertokusumo, Op-cit, hal.143.
} 
untuk memberi makna terhadap undangundang dengan bertitik tolak pada pemakaian bahasa sehari-hari.

2. Interpretasi sistematis/logis, yaitu metode yang digunakan oleh hakim untuk menjelaskan undang-undang dengan cara menghubungkan peraturan perundang-undangan itu dengan peraturan hukum lainnya atau keseluruhan sistem hukum yang berkaitan dengan hukum yang dimaksud.

3. Interpretasi sosiologis atau teleologis, yaitu merupakan metode penafsiran yang digunakan oleh hakim dengan cara memformulasikan undang-undang menurut tujuan dan jangkauan pembuat undang-undang tersebut.

4. Interpretasi historis/sejarah, yaitu merupakan penafsiran makna undangundang menurut terjadinya. Metode interpretasi historis terdiri dari interprestasi sejarah hukum dan interpretasi menurut sejarah terjadinya undang-undang.

5. Interpretasi komparatif, merupakan metode penemuan hukum dengan cara membandingkan ketentuan pada satu sistem hukum dengan ketentuan yang pada sistem hukum yang lain.

6. Interpretasi antisipatif/futuristik, merupakan suatu metode menginterpretasikan suatu ketentuan undang-undang dengan cara merujuk pada ketentuan undang-undang yang belum memiliki kekuatan berlaku atau masih dibicarakan di lembaga legislatif. ${ }^{20}$

Di luar metode interpretasi diatas, ada istilah penghalusan hukum. Penghalusan hukum sering disebut dengan penyempitan hukum, karena pada umumnya pemberi batasan tertentu pada undang-undang yang bersifat umum, mengakibatkan pengertian bunyi dalam undang-undang itu sempit. Disamping itu, penyempitan hukum digunakan apabila pengaturan undang-undang terlalu luas atau umum, maka undang-undang itu dipersempit ruang lingkungannya agar dapat diterapkan pada suatu peristiwa konkret yang belum ada pengaturannya.

\footnotetext{
${ }^{20}$ Ellyne D Poespasari, Op-cit, hal.144.
}

Sudikno Mertokusumo ${ }^{21}$ menyebutkan, bahwa penafsiran ekstensif merupakan penafsiran yang melampaui batas yang diberikan pada penafsiran gramatikal. Adapun penafsiran restriktif, sebagai metode menemukan hukum merupakan hasil dari interpretasi itu sendiri. Misalnya, interpretasi gramatikal dan interpretasi sistematis pada umumnya bersifat membatasi (restriktif), sedangkan interpretasi historis, interpretasi teleologis dan argumentasi, analogis umumnya bersifat memperluas (ekstensif).

Menurut Soepomo memberikan pengertian tentang hukum adat, bahwa hukum adat sebagai hukum yang tidak tertulis di dalam peraturan legislatif (unstatutory law), meliputi peraturan-peraturan hidup yang meskipun tidak ditetapkan oleh yang berwajib, tetapi tetap ditaati dan didukung oleh rakyat berdasarkan keyakinan, bahwa peraturanperaturan tersebut mempunyai kekuatan hukum. ${ }^{22}$ Oleh sebab itu, dapat dikatakan bahwa hukum yang hidup sebagai konvensi pada badan-badan hukum negara (parlemen), hukum yang timbul karena keputusan hakim (judge made law), hukum yang hidup sebagai peraturan kebiasaan yang dipertahankan di dalam pergaulan hidup baik di kota-kota maupun di desa-desa (customary law), sehingga hukum adat merupakan suatu norma hukum yang berakar pada nilai-nilai budaya bangsa Indonesia sepanjang sejarah mengalami penyesuaian dengan keadaan, artinya bersifat terbuka menerima norma-norma dari luar sepanjang tidak bertentangan dengan adat atau budaya bangsa Indonesia sendiri. Disamping itu, Bushar Muhammad, ${ }^{23}$ mengemukakan bahwa hukum yang tidak tertulis hanya meliputi hukum yang hidup dan dipertahankan sebagai peraturan adat di dalam masyarakat (customary law), yang disebut hukum adat dalam arti sempit, namun juga kebiasaan dalam ketatanegaraan (convention) dan kehakiman atau peradilan.

Berdasarkan kedua pendapat diatas, hukum kebiasaan atau hukum adat juga dapat merupakan sumber hukum, yang posisinya

\footnotetext{
${ }^{21}$ Sudikno Mertokusumo, Op-cit, hal.69.

${ }^{22}$ Soepomo, Bab-bab tentang Hukum Adat, Pradnya Paramita, Jakarta, 1993, hal.41.

${ }^{23}$ Bushar Muhammad, Asas-Asas Hukum Adat Suatu

Pengantar, Pradnya Paramita, Jakarta, 1994, hal.12
} 
berada di bawah undang-undang. Oleh sebab itu, berkaitan dengan cara hakim (UndangUndang Nomor 48 Tahun 2009) menyelesaikan sengketa hukum waris adat, yang dasarnya hukum adat itu tidak tertulis, maka hakim tidak boleh menolak perkara yang ada, hakim harus menggali dan mengikuti serta memahami nilainilai hukum dan rasa keadilan yang hidup dalam masyarakat. Hal ini terdapat dalam Pasal 10 ayat 1 UU Nomor 48 Tahun 2009 tentang Kekuasaan Kehakiman yang menentukan, bahwa hakim dilarang menolak untuk memeriksa dan mengadili suatu perkara yang diajukan kepadanya, dengan alasan undangundang tidak ada atau tidak jelas. Dalam hal ini hakim selalu dituntut untuk melengkapi undang-undang sebagaimana yang diatur dalam Pasal 5 ayat 1 Undang-Undang Nomor 48 Tahun 2009 tentang Kekuasaan Kehakiman yang menegaskan, bahwa hakim wajib menggali, mengikuti dan memahami nilai-nilai hukum dan rasa keadilan yang hidup dalam masyarakat. Ketentuan dalam pasal tersebut akan menjadi salah satu dasar hukum bagi hakim untuk menemukan hukumnya berdasarkan hukum kebiasaan atau hukum adat.

Berdasarkan Pasal 50 ayat 1 dan ayat 2 UU Nomor 48 Tahun 2009 tentang Kekuasaan Kehakiman hanya mensyaratkan agar semua putusan pengadilan, selain memuat alasan dan dasar putusan, juga harus memuat pasal tertentu dari peraturan perundang-undangan yang bersangkutan atau sumber hukum yang tidak tertulis yang dijabarkan untuk mengadili. Putusan hakim harus ditandatangani oleh ketua majelis hakim dan hakim anggota yang memutus perkara serta panitera yang ikut bersidang, kemudian putusan tersebut diucapkan dalam persidangan terbuka untuk umum.

Dalam penyelesaian masalah hukum, hakim dapat bersumber kepada aturan hukum yang tertulis dan aturan hukum yang tidak tertulis, apabila hakim (UU Nomor 48 Tahun 2009) dalam menyelesaikan perkara yang bersumber pada hukum yang tidak tertulis (hukum adat), maka ada 2 (dua) hal yang harus diperhatikan, yaitu :

a. Dalam memberikan putusan, pengadilan berpedoman kepada suatu kaidah ketentuan hukum substantif dari hukum adat. Kaidah hukum substantif ditemukan sebagai suatu kaidah ataupun sebagai aturan empiris yang dinyatakan sebagai adat kebiasaan. Kaidah hukum yang substantif tersebut oleh pengadilan sebagai suatu kaidah atau ketentuan yang dalam bentuknya sudah memerinci secara jelas sebagaimana halnya kaidah substantif dalam hukum yang dikodifikasi.

b. Putusan yang didalamnya mencerminkan asas-asas yang bersifat umum yang digunakan untuk menggali perkaraperkara yang berkaitan dengan hukum adat. Asas-asas yang dinyatakan dengan "rasa keadilan", mengadili menurut "kebijaksanaan" (in goede justitie) atau menurut Koesnoe menggunakan istilah " sesuai dengan keadaan zaman dan tempat", dan "patut". Asas-asas yang digunakan oleh pengadilan sebagai pedoman dalam memberikan putusan mengenai perkara-perkara adat yang berbeda-beda. Istilah yang banyak digunakan adalah patut, keadilan, pantas, layak, sebaik-baiknya alur, sesuai dengan keadaan zaman dan setempattempat dan laras. ${ }^{24}$ Oleh karena itu, hakim dalam memutus sengketa waris adat mempunyai metode yang berbeda dengan menyelesaikan yang didasarkan pada hukum yang tertulis (peraturan perundang-undangan). ${ }^{25}$

Koesno menyatakan, ${ }^{26}$ bahwa pikiran yang dianut oleh pengadilan (Mahkamah Agung) dalam menyelesaikan sengketa hukum waris adat mencerminkan pendirian bahwa hukum adat terdapat dalam kaidah yang substantif. Pikiran ini timbul adanya pengaruh teori yang disampaikan Ter Haar dan murid-muridnya, sehingga terlihat adanya suatu kecenderungan di dalam kalangan pengadilan mulai pengadilan negeri sampai pada Mahkamah Agung untuk menyusun yurisprudensi di dalam hukum adat. Dengan demikian, berarti aka nada perumusan yang terperinci dan tegas ketentuan-ketentuan

\footnotetext{
${ }^{24}$ M.Koesno, Catatan Terhadap Hukum Adat Dewasa Kini, Airlangga University Press, Surabaya, 1974, hal.38.

${ }^{25}$ Ellyne D Poespasari, Op-Cit, hal.148.

${ }^{26}$ Ibid, hal.39.
} 
substantif di dalam hukum waris adat yang akan mengarah pada hukum kodifikasi. ${ }^{27}$

Ajaran Ter Haar dikenal dengan nama Beslissingenleer. Berdasarkan ajaran ini, maka hukum adat itu dengan mengabaikan bagianbagiannya yang tertulis yang terdiri dari peraturan-peraturan desa, surat-surat perintah raja adalah keseluruhan peraturan-peraturan yang menjelma dalam keputusan-keputusan para fungsionaris hukum yang mempunyai wibawa serta pengaruh dan yang dalam pelaksanaannya berlaku serta merta (spontan) dan dipatuhi dengan sepenuh hati. ${ }^{28}$

Hukum adat yang berlaku itu hanya dapat diketahui dan dilihat dalam bentuk-bentuk keputusan-keputusan para fungsionaris hukum itu, bukan hakim saja melainkan kepala adat, rapat desa, dan wali tanah. Keputusan itu bukan saja keputusan mengenai suatu sengketa yang resmi, namun juga di luar itu berdasarkan nilai-nilai yang hidup sesuai dengan alam rohani dan hidup kemasyarakatan anggota-anggota persekutuan itu. ${ }^{29}$

Hal ini, Ter Haar tidak dapat melupakan kenyataan-kenyataan dalam masyarakat Indonesia dan cara berpikir yang khas yang harus dipakai oleh seorang hakim yang bijaksana sebagai pangkal haluan. Oleh sebab itu, sangat penting bagi hakim itu untuk mencari penyelesaian perkara yang dihadapinya, untuk memberi keputusan hukum, berdasarkan keyakinan sendiri dalam pengaruh timbal balik dengan segala sesuatu yang menjadi keyakinan rakyat. ${ }^{30}$ Keputusan hakim harus menjadi pemikul yang nyata dari nilai-nilai kerohanian serta nilai-nilai kemasyarakatan dalam hidup bersama dalam persekutuan.

\section{PENUTUP}

\section{A. Kesimpulan}

1. Hukum Adat Indonesia yang normatif pada umumnya menunjukkan corak

Tradisional, keagamaan, kebersamaan, konkret dan Visual, terbuka dan sederhana, dapat berubah dan menyesuaikan, tidak dikodifikasi serta musyawarah dan mufakat dan mengenai

\footnotetext{
${ }^{27}$ Ellyne D Poespasari, Op-cit, hal.149..

${ }^{28}$ Ibid, hal.149.

${ }^{29}$ Bushar Muhammad, Op-cit, hal.8.

${ }^{30}$ Ellyne D Poespasari, Op-cit, hal.150.
}

proses pewarisannya sebelum pewaris meninggal dunia dilaksanakan dengan cara penerusan atau pengalihan, cara penunjukkan serta cara meninggalkan pesan atau wasiat dan sesudah pewaris meninggal dunia, dilaksanakan dengan penguasaan harta waris dan pembagian harta waris.

2. Cara hakim menyelesaikan sengketa hukum waris adat, yang pada dasarnya hukum adat itu tidak tertulis, hal ini terdapat dalam Pasal 10 ayat 1 dan Pasal 5 ayat 1 Undang-Undang Nomor 48 Tahun 2009 yang menentukan bahwa hakim dilarang menolak suatu perkara dan wajib menggali, mengikuti dan memahami nilai-nilai hukum dan rasa keadilan yang hidup dalam masyarakat. Ketentuan pasal ini akan menjadi salah satu dasar hukum bagi hakim untuk menemukan hukumnya berdasarkan hukum kebiasaan atau hukum adat serta berdasarkan Pasal 50 ayat 1 dan 2 yang mensyaratkan agar semua putusan pengadilan, selain memuat alasan dan dasar putusan, juga harus memuat pasal tertentu dari peraturan perundangundangan yang bersangkutan atau sumber hukum yang tidak tertulis yang dijabarkan untuk mengadili.

\section{B. Saran}

Perubahan dalam hukum adat tidaklah selalu dilakukan dengan menghilangkan aturanaturan dalam hukum adat yang lama dan mengganti aturan-aturan yang baru, tetapi dengan cara membiarkan adat yang lama membentuk suatu yang baru dengan tetap mempertahankan prinsip yang ada. Hal ini harus dipahami oleh hakim dalam menyelesaikan sengketa hukum waris adat yang ada di Indonesia demi menjadikan hukum adat tetap bertahan di tengah-tengah perkembangan zaman dan hukum adat pada dasarnya yang diharapkan mampu menyesuaikan diri dengan tatanan masyarakat yang modern, seperti yang terjadi dalam pembayaran jujur dalam perkawinan adat Batak yang tidak lagi menghiraukan adanya pembayaran uang jujur karena penyesuaian kemampuan perempuan, namun pembayaran 
uang jujur kepada suami dan kerabat masih tetap ada.

\section{DAFTAR PUSTAKA}

Ali Zainudin, Pelaksanaan Hukum Waris di Indonesia, Sinar Grafika, Jakarta, 2008.

Elmiyah Nurul, Rosa Agustina dan Erman Rajagukguk, Hukum Adat dalam Putusan Pengadilan, Lembaga Studi Hukum dan Ekonomi, Fakultas Hukum Universitas Indonesia, 2007.

Koesno M, Catatan Terhadap Hukum Adat Dewasa Kini, Airlangga University Press, Surabaya, 1974.

Leyn Gregory, Hermeneutika Hukum, Sejarah, Teori Politik (terjemahan M.Khozim), Nusa Media, Bandung, 2008.

Mertokusumo Sudikno, Penemuan Hukum Sebuah Pengantar, Liberty, Yogyakarta, 2007.

Mudaris Zaini, Adopsi Suatu Tinjauan dari Tiga Sistem Hukum, Sinar Grafika, Jakarta, 1992.

Muhammad Bushar, Asas-Asas Hukum Adat Suatu Pengantar, Pradnya Paramita, Jakarta, 1994.

Hadikusuma Hilman, Hukum Waris Adat, Citra Aditya, Bandung, 1999.

Harahap Yahya, Kedudukan Janda, Duda, Anak Angkat dalam Hukum Adat, 1993, Citra Aditya Bakti, Jakarta, 1993.

Hazairin, Hukum Kewarisan Bilateral menurut Al-Quran, Tinta Mas, Jakarta, 1960.

Isdiyanto Yuli Ilham, Rekonstruksi Hukum \& Ketatanegaraan Indonesia,UII Press, Yogyakarta, 2017.

Poespasari Dwi Ellyne, Pemahaman Seputar Hukum Waris Adat Di Indonesia, Prenada Media Group Jakarta,2018

Rahardjo Satjipto, Biarkan Hukum Mengalir, Kompas, Jakarta, 2007.

Saragih Djaren, Pengantar Hukum Adat Indonesia, Tarsito, Bandung, 1982.

Sidharta B. Arif, Penalaran Hukum, Loka Latih Studi Hukum Kritis dan Pluralisme Hukum, Fakultas Hukum Universitas Tanjungpura Pontianak, 2005.

Sudiyat Imam, Hukum Adat Sketsa Asas, Liberty, Yogyakarta, 1990.
Subekti, Pokok Pokok Hukum Perdata, Pradnya Paramita, Jakarta, 1983. dan Tjitrosudibio, R, Kitab Undang-Undang Hukum Perdata, Terjemahan Burgelijk Wetboek, Pradnya Paramita.

Soepomo, Bab-bab tentang Hukum Adat, Pradnya Paramita, Jakarta, 1983.

------------, Hubungan Individu dan Masyarakat dalam Hukum Adat, Pradnya Paramita, Jakarta, 1978.

Soekanto S dan Mamudji S, Penelitian Hukum Normatif Suatu Tinjauan Singkat, PT RajaGrafindo Persada, 1995.

Ter Haar, Asas-asas dan Susunan Hukum Adat, Terjemahan K, Ng Soebakti Poesponoto, Pradnya Paramita, Jakarta, 1999.

Thalib Sayuti, Hukum Kekeluargaan Indonesia, UI Press, Jakarta,1986.

Vollmar, Hukum Keluarga Menurut KUH Perdata, Tarsito, Bandung, 1990.

Wignjodipuro, Pengantar Dan Asas-Asas Hukum Adat, Gunung Agung, Jakarta, 1994. 